\title{
Sharing Views of CLIL Lesson Planning in Language Teacher Education
}

\section{Miradas sobre la planificación de clases de AICLE en la formación docente en lengua inglesa}

\author{
Darío Luis BANEGAS \\ University of Warwick, Coventry, UK \\ d.banegas@warwick.ac.uk
}

\begin{abstract}
Argentina seems to favour CLIL (content and language integrated learning) as a language-driven approach in secondary and higher education. In this paper, I investigate curriculum development and lesson planning based on trainees' perceptions and lesson plans submitted to pass a module on Didactics as part of their formal initial English language teacher education. My aim is to compare what a group of trainees does in relation to the notion of CLIL as forward curriculum planning and the frameworks posited in the CLIL literature. My theoretical framework is guided by the concept of didactic transposition applied to CLIL and the literature on CLIL lessons plans drawing on teachers' voices through their plans. In this paper I discuss how language-driven CLIL was envisaged by a group of 47 trainees enrolled in a teacher education course in southern Argentina. Data emerged from a survey and lesson plans aimed at secondary-school learners for whom English was usually taught two hours a week. Results show that language-driven CLIL follows forward design; it focuses more on content than on explicit knowledge of the language, and it is aimed at revising language with older learners.
\end{abstract}

Keywords: language-driven CLIL; didactic transposition; lesson plans; language skills; language teacher education.

\section{Resumen}

La Argentina tiende a adoptar el enfoque AICLE desde una preponderancia sobre el aprendizaje de otra lengua en la educación secundaria y el nivel superior. En este artículo investigo el desarrollo curricular y la planificación de clases con base en las percepciones y los planes de clases elaborados por un grupo de futuros docentes graduados para el espacio Didáctica como parte de su formación inicial como profesores de inglés. El objetivo es comparar las elaboraciones que este grupo de estudiantes realiza en relación con la noción de AICLE como un currículo lineal y los marcos propuestos en la literatura sobre AICLE. El marco teórico de esta contribución está guiado por el concepto de transposición didáctica aplicado a AICLE y la literatura sobre secuencias didácticas de AICLE según las voces de los docentes. En este artículo se analizan las miradas que un grupo de 47 estudiantes del profesorado de inglés en el sur de Argentina posee sobre AICLE enfocado en la lengua. Los datos surgen a partir de una encuesta y los planes de clase pensados para estudiantes secundarios con una carga horaria de Inglés de dos horas semanales. Los resultados indican que AICL enfocado en la lengua sigue un currículo lineal, se centra en el contenido sobre el conocimiento explícito de la lengua, y se propone como espacio de repaso de la lengua con estudiantes más grandes.

Palabras clave: AICLE orientado a la lengua; transposición didáctica; planificación de clases; prácticas del lenguaje; formación docente en lengua.

Received: 2015-02-12 / Sent for peer review: 2015-02-12 / Accepted by peers: 2015-05-13 / Approved: 2015-05-20

To reference this article / Para citar este artículo

Banegas, D. L. (2015). Sharing views of CLIL lesson planning in language teacher education. Latin American Journal of Content and Language Integrated Learning, 8(2), 104-130. doi:10.5294/laclil.2015.8.2.3 


\section{INTRODUCTION}

According to Dalton-Puffer, Llinares, Lorenzo, and Nikula (2014):

Classrooms the world over are full of people who, for different reasons, are learning additional languages and/or are studying through languages that are not their first. (p. 213)

CLIL (Content and Language Integrated Learning) is an umbrella term that includes different conceptualisations for the integration of curriculum content and language learning. In its inception, CLIL was a European initiative and since then it has found its way in contexts outside Europe, as noted in Ruiz de Zarobe (2013). For some time, we have heard of CLIL as a continuum from content-driven CLIL to language-driven CLIL or CLIL with a dual focus (see Mehisto, Marsh, \& Frigols, 2008, pp. 11-19). While Europe seems to be narrowing CLIL down to the content end of this continuum (see Dalton-Puffer \& Nikula, 2014; Koopman, Skeet, \& de Graff, 2014; Ruiz de Zarobe \& Cenoz, 2015), Latin America embraces CLIL from a broader stance (Mariño Avila, 2014; Curtis, 2012; Matear, 2008; Ravelo, 2013).

Argentina seems to favour CLIL as a language-driven approach in secondary and higher education, as recent publications illustrate (Banegas, 2011, 2013; Liendo, 2012; Rafel, 2011; Ravelo, 2014). Through recent educational reforms, CLIL has been suggested as a possible teaching framework in new secondary education curricula (see Bracchi, 2010; Braun, Cabral, \& Cheme Arriaga, 2013). English as a foreign language (EFL) is gradually being incorporated in primary education and has become more present in secondary education. Usually, secondary-school learners have three 40-minute teaching periods of EFL each week. CLIL has also been included as content in English Language Teaching (ELT) Didactics in initial languageteacher education programmes (Banegas, 2014).

Therefore, in this contribution, I approach CLIL from a languagedriven perspective, as my experience as a teacher and teacher educator in CLIL is rooted within the EFL lesson. From this angle, I discuss 
curriculum development and lesson planning based on trainees' perceptions and lesson plans submitted as part of their initial teacher education programme. My theoretical framework is guided by the concept of didactic transposition applied to CLIL and the literature on CLIL lessons plans drawing on teachers' voices through their plans.

\section{CLIL CURRICULUM AND LESSON PLANNING}

For reasons of space, I cannot elaborate on the history of didactic transposition (DT); however, readers can find a comprehensive review in Gómez Mendoza (2005). What is important to remember is that, in a nutshell, we may define DT as the transformations that operate between content development and selection and how teachers and learners engage with it in the classroom. DT is underpinned by notions of power relation, context, and conceptions of knowledge and one part of its transformations could be crystallised in curriculum development. The other part, the classroom, will be available to us through lesson plans, classroom accounts, and curriculum enactment.

As regards curriculum development in general, Richards (2013) proposes 3 curriculum design strategies:

Forward design starts with syllabus planning, moves to methodology, and is followed by assessment of learning outcomes. Resolving issues of syllabus content and sequencing are essential starting points with forward design, which has been the major tradition in language curriculum development. Central design begins with classroom processes and methodology. Issues of syllabus and learning outcomes are not specified in detail in advance and are addressed as the curriculum is implemented. Many of the innovative methods' of the 1980s and 90s reflect central design. Backward design starts from a specification of learning outcomes and decisions on methodology and syllabus are developed from the learning outcomes. (p. 5)

According to Richards, CLIL is an example of forward curriculum design because: 
The process of developing a curriculum typically starts with the design of a syllabus that contains both content and language components. This then leads to the choice of suitable instructional materials as well as selection of activities for delivering, reviewing and assessing instruction [...]. (Richards, 2013, p. 12).

In the same article, Richards claims that once content (language and content in CLIL) and syllabus are agreed (in that order), then methodology, outcomes, and assessment are discussed (again in that linear fashion).

If we follow Richard's sequence above, CLIL methodology is, supposedly, brought to the foreground once content and syllabus are clear. Mehisto, Marsh, and Frigols (2008, p. 29) summarise the core features of CLIL methodology as follows:

- Multiple focus

- $\quad$ Safe and rich learning environment

- Authenticity

- Active learning

- Scaffolding

- Cooperation

Needless to say, these core features are not CLIL-exclusive. Mehisto et al. (2008, p. 101) add that such a methodology needs to be guided by 3 clear outcomes:

- Content-related learning outcomes

- Language-related learning outcomes that support the acquisition of content

- $\quad$ Outcomes related to general learning skills.

More recently, some authors have examined and stressed the centrality of learner motivation (Doiz, Lasagabaster, \& Sierra, 2014), autonomy (Adamson, 2014), and authenticity (Pinner, 2013) in the CLIL classroom.

Mehisto et al.'s (2008) book may be said to be the first title that condensed CLIL underpinnings, classroom accounts, and varied activities and suggestions for the CLIL classroom, whether this is 
content- or language-driven. Throughout the book, the authors remark that lessons should include opportunities for cognition, community, content, and communication. However, no sample lesson plans are provided.

In 2010, Coyle, Hood, and Marsh published their book titled CLIL: Content and Language Integrated Learning. Similarly to Mehisto et al. (2008), they provide an ample gamut of curricular models, stress cognitive development in line with Bloom's revised taxonomy, and introduce two new working frameworks: (1) The language triptych to ensure that language learning includes content-specific discourse and language to complete tasks successfully; and (2) the 4Cs framework to ensure holistic and contextualised learning which includes content, communication, cognition, and culture. With reference to language, there have been more recent developments about the roles of language in CLIL; that is, the language of academic subjects and the role of language in CLIL classroom interaction (see Llinares, Morton, \& Whittaker, 2012).

Coyle et al. (2010) include a sample CLIL lesson plan that consists of two parts. The topic is ecosystems and it is targeted at $4^{\text {th }}$-grade learners in primary education. Part 1 includes information about the global goal, topic, level, aims, criteria for assessment, teaching objectives (following the two frameworks I mention above), and learning outcomes. Part 2 contains bulleted activities, instruments for assessment, scaffolding tips, resources, and additional notes. The structure of the lesson is contained in the set of activities (Coyle et al.2010, p. 82):

- Warm up: Let's think (PowerPoint). General overview of the unit.

- $\quad$ Previous knowledge: Starting a KWL chart. Learners see and listen to different features of animals.

- Game: In order to check their comprehension, learners play a challenging game called 'I bet it's true!'

- Ending the lesson: Learners think about animals that might live in dry/cool places. 
- Glossary: Time to think about new words that learners do not know. One of the learners writes down (on a poster) which words they decided to choose.

In a similar vein, Bentley (2010, pp. 32-33) offers a CLIL science lesson plan on magnetism (materials and their properties) for young learners. The plan includes content, teaching aims, learning outcomes, assessment, communication (vocabulary, structures, and functions), cognition, citizenship, resources, and the procedures for developing the lesson. For example, the lesson starts with a whole class activity for the activation of prior knowledge. Learners are expected to look around the classroom, identify an object and describe what it is made of. The lesson finishes with a follow-up activity that consists of investigating and separating school rubbish for recycling.

Both lesson plans above have young learners in mind. In addition, content and language are integrated throughout the lesson. Language learning takes place mostly through noticing, and prior knowledge becomes the core of the plan. In this regard, knowledge generation is mainly inductive as learners assume a 'researcher' role by engaging in observing, classifying, and elaborating broader concepts. In relation to learners' roles, Coyle (2013) calls for the incorporation of learners' voices as part of CLIL explorations and classroom practices.

Following this framework, I sought to examine how practicing teachers conceptualise CLIL according to perceptions of their own practices and lessons plan submitted to pass a module on Didactics as part of their formal initial English language teacher education. I wish to compare what a group of teachers does in relation to the notion of CLIL as forward curriculum planning and the frameworks posited in the CLIL literature that I summarised above.

\section{METHOD}

The research group consisted of 47 unqualified practicing teachers in Argentina (henceforth trainees), who attended an online initial teacher education course to obtain their teaching degrees as teachers of English 
(see Banegas \& Manzur Busleimán, 2014). The trainees belonged to the 2012, 2013, and 2014 cohorts when they had online distance lessons with me as their Didactics tutor. The trainees were mostly female, between 20-40 years old, and on average they had around 5 years of teaching experience. Most of the trainees had different teaching posts at both state and private schools in Argentina, but this situation may have varied even within a given year, and therefore it is difficult to produce a general picture of their professional contexts.

In the Didactics module, we studied ELT for teenage learners. The core contents were: motivation and autonomy, learning strategies, reflective teaching, cognitive processes, lesson planning for CLT (Communicative Language Teaching), TBL (Task-Based Learning), and language-driven CLIL, teaching grammar and vocabulary, skills development, assessment, curriculum design, materials, and classroom management.

Data come from a survey and lesson plans submitted as part of the Didactics module. The survey was completed by the 47 trainees. The non-mandatory survey, completed online, was based on a checklist designed by Dale and Tanner (2012, pp. 15-18). The aim of the survey was to introduce CLIL by reflecting on trainees' practices. They were asked to complete it before starting the unit on language-driven CLIL. The survey can be seen in the Appendix: Survey section or accessed online. ${ }^{1}$

As regards lesson plans, I collected 39 lesson plans from the three cohorts produced for language-driven CLIL with the aim of examining how these trainees conceptualised CLIL in their contexts. I should clarify that only 39 out of the 47 trainees completed this assignment, among others, to produce a language-driven CLIL lesson plan. In addition, I wished to explore their management of activities, materials, and dual focus of language and content. These plans were part of the module assignments. Trainees were free to choose the content and

1 See https://docs.google.com/forms/d/1O67PVZqh-qtMv64Yuiaf2rzyjzKNVrSfFYyh_h948jA/viewform?edit_ requested=true. 
the context of their lesson. They had only been provided with Coyle et al.'s (2010) sample lesson plan (see the CLIL curriculum and lesson planning section) and introductory literature on CLIL.

\section{RESULTS}

\section{Survey results}

In total, the survey was completed by 47 trainees between 2012 and 2014. Using a Likert scale, the trainees had to rate the extent to which they engaged with the teaching strategies listed. They could rate the items as always, often, sometimes, occasionally, and never. Table 1 shows the actual number of responses for each item.

\section{Table 1. How CLIL are you?}

\begin{tabular}{|c|c|c|c|c|c|}
\hline Item & A & Of & S & Oc & $\mathrm{N}$ \\
\hline 1. At the start of a lesson, I find out what learners know about the topic. & 39 & 5 & 1 & 2 & 0 \\
\hline $\begin{array}{l}\text { 2. At the start of a lesson, I find out what language related to the topic learners } \\
\text { already know. }\end{array}$ & 29 & 14 & 2 & 2 & 0 \\
\hline 3. I use visuals to introduce new topics. & 17 & 23 & 4 & 2 & 1 \\
\hline 4. I use hands-on activities to introduce new topics. & 7 & 15 & 15 & 5 & 5 \\
\hline 5. I use graphic organisers to find out and organise what learners know. & 6 & 14 & 13 & 9 & 5 \\
\hline 6. I ask learners to talk to each other when I am activating prior knowledge. & 7 & 13 & 11 & 10 & 6 \\
\hline 7. I provide different sorts of input to help understanding. & 17 & 21 & 7 & 1 & 1 \\
\hline $\begin{array}{l}\text { 8. I formulate different questions to promote lower-order and higher-order } \\
\text { thinking skills. }\end{array}$ & 17 & 23 & 5 & 1 & 1 \\
\hline 9. I encourage my learners to interact through pair and group work. & 18 & 17 & 5 & 5 & 2 \\
\hline 10. I use graphic organisers to support understanding of input. & 9 & 13 & 14 & 9 & 2 \\
\hline $\begin{array}{l}\text { 11. I use a number of strategies or activities to help learners improve their } \\
\text { reading and listening skills. }\end{array}$ & 20 & 17 & 7 & 2 & 1 \\
\hline 12. I work actively with my learners on developing their thinking skills. & 18 & 19 & 6 & 2 & 2 \\
\hline 13. I use a variety of activities to help my learners to recycle vocabulary. & 16 & 23 & 8 & 0 & 0 \\
\hline 14. I help learners notice how language is used in the topic of the lesson. & 30 & 9 & 7 & 0 & 1 \\
\hline $\begin{array}{l}\text { 15. I help learners notice the similarities and differences between English and } \\
\text { their first language. }\end{array}$ & 8 & 17 & 11 & 9 & 2 \\
\hline 16. In my classes, learners use a personal vocabulary file actively. & 4 & 4 & 11 & 20 & 8 \\
\hline 17. I help my learners learn and use subject-specific terminology. & 12 & 16 & 15 & 4 & 0 \\
\hline 18. I discuss ways of learning words with my classes. & 7 & 18 & 10 & 8 & 4 \\
\hline
\end{tabular}


In general, always and often were the most popular answers selected by the trainees. Thus, we may say that they had experience with integrating content into their EFL lessons.

However, I noted that some items obtained less polarised responses. For example, a focus on visuals and graphic organisers (items 5 and 10 in Table 1) received a less unanimous response. Similarly, there was a visible difference between items 14 and 15 as regards language awareness and noticing. While trainees seemed to promote language noticing, they did not tend to do so through L1-L2 comparisons or metalinguistic reflection.

In addition, I noted that pair-work was not encouraged (items 6 and 9 in Table 1). On the other hand, items 16 and 18 appear to show that vocabulary development was not in the learners' hands. These 4 items may reveal that learner autonomy was not a central or systematic feature of these trainees' practices. Perhaps, these items, together with those on pair-work, may indicate that lessons were more teacher- than learner-centred.

\section{LESSON PLANS: FROM LEARNERS' LEVEL TO AIMS}

For the purposes of content analysis of the 39 lessons plans submitted by the trainees, I produced a table with the following aspects: learners' level, structure, and (more importantly) content, language, aims, language activities, content activities, and materials.

In relation to learners' level, the trainees tended to have teenagers with some years of learning English as their target group. Drawing on CEFR levels, 4 lesson plans had A2 learners in mind. B1 learners were the target group of 31 plans, and only 4 lesson plans were aimed at B2 learners.

As regards structure - that is, the formal breakdown of a lesson into stages or parts - all lesson plans aimed at 80-minute lessons (typical time length in secondary education in Argentina) that included the following stages as named by the trainees: 
1. A warm-up stage, through which prior knowledge was activated and elicited.

2. A development stage, usually consisting of between 4 and 5 activities to introduce and engage with the target content and language.

3. A closure stage, through which the teacher recapped the contents of the lesson and set homework.

The reason for such uniformity may come from previous lesson planning formats. In other modules of the course (ELT Practice and Introduction to Didactics), trainees were encouraged to structure their lesson plans around 3 broad stages: warm-up (this includes elicitation and presentation of the new content), development (this includes focus on grammar and/or vocabulary and guided practice), and closure (free practice, wrap-up and setting homework).

By content, I mean the non-language aspect of the lesson plan; that is, the curriculum areas that are brought into the EFL/languagedriven CLIL lesson. Table 2 shows the content areas and examples of topics found.

Table 2. Trainees' most preferred contents

\begin{tabular}{|l|c|l|}
\hline \multicolumn{1}{|c|}{ Area/Subject } & $\begin{array}{c}\text { Number of } \\
\text { lesson plans }\end{array}$ & \multicolumn{1}{c|}{ Examples of contents } \\
\hline Physical Geography & 12 & $\begin{array}{l}\text { The solar system, rivers, climate and } \\
\text { weather, natural disasters }\end{array}$ \\
\hline Human Geography & 10 & Migration, population growth, tourism \\
\hline Biology & 10 & $\begin{array}{l}\text { Circulatory system, respiratory system, } \\
\text { sight }\end{array}$ \\
\hline History & 2 & Stone age \\
\hline Technology & 2 & ICT, engines \\
\hline Literature & 1 & The Iliad and The Odyssey \\
\hline Other & 2 & Religions in the UK \\
\hline
\end{tabular}

By language, I mean the pedagogical treatment of EFL into units such as grammar, discourse function, lexis, and phonology. I noted that out of the 39 lesson plans, 30 of them included functions such as describing, expressing opinions, or narrating together with grammar 
points such as tenses and passive voice. Nine (9) lesson plans included grammatical aspects only (for example, comparative and superlative adjectives). However, functions such as describing or explaining were present, if only peripherally. All lessons plans contained a clear focus on vocabulary. Nonetheless, not all of them included explicit instances of language of/for learning. In other words, all lesson plans featured content-obligatory language, such as specific terminology (for example, parts of the respiratory system), but only a few of them also offered language work needed to complete tasks (such as producing a cohesive text, or making a presentation to compare and contrast planets).

In all lesson plans, trainees first selected the content and language before setting lesson aims. In general terms, the trainees included between 3 and 4 aims. According to my content analysis, these could be grouped under three interrelated categories: language aims, content aims, and learning aims. However, not all the trainees aimed at these three categories. In some cases, they included content and learning aims. In some other cases, they included language and content aims only. Table 3 illustrates some of these aims.

Table 3. Types of lesson aims

\begin{tabular}{|c|c|}
\hline Type of aim & Examples \\
\hline Language & $\begin{array}{l}\text { - To develop language awareness. } \\
\text { - To improve speaking skills through a presentation. } \\
\text { - To use comparative and superlative adjectives. } \\
\text { - To use grammatical categories correctly. } \\
\text { - To use specific vocabulary. }\end{array}$ \\
\hline Content & $\begin{array}{l}\text { To learn about the solar system. } \\
\text { - To learn about rivers in the Americas. } \\
\text { - To identify functions and structure of bones. } \\
\text { - To raise awareness of how the eye works. } \\
\text { - To explain the respiratory system. }\end{array}$ \\
\hline Learning & $\begin{array}{l}\text { To work collaboratively. } \\
\text { - To develop summarising strategies. } \\
\text { - To encourage quality internet search. } \\
\text { - To develop analytical strategies. } \\
\text { - To understand visual information. }\end{array}$ \\
\hline
\end{tabular}


However, I should highlight that I felt that aims such as 'to distinguish and talk about causes and consequences' or 'to describe a process' could be seen as language, content, and learning aims. On the one hand, such aims depend on a specific content (for example, migration or the respiratory system). On the other hand, these aims also respond to different cognitive skills that go beyond content specificity and aim at empowering learners with lower-order as well as higher-order thinking skills. In addition, learners need specific linguistic tools to, for instance, describe a process (for example, simple present, and connectors to express order).

\section{LESSON PLANS: FROM ACTIVITIES TO MATERIALS}

CLIL aims at developing a holistic and integrated approach for content and language learning. In other words, it is not the sum of its parts that produce CLIL, but the interdependent dialogue between them. All activities are carried out through language; thus, all activities are language activities in any subject at school. For instance, even if learners are asked to turn a mind-map into a summary, there is content and, of course, there is language involved at different levels and sub-systems. Yet I wished to see which activities tended to have a language or a content focus, so that I could see the extent to which aims were materialised in the lesson plans and in what ways this group of trainees envisaged language-driven CLIL.

As a first step, I counted the number of activities and divided them between language activities and content activities. I mentioned previously that, on average, lesson plans included between 4 and five activities. However, I should clarify that at one end, 1 lesson plan included 2 activities; at the other end of the spectrum, 2 lesson plans contained 8 activities. I consider language activities those that involved discourse, grammar, and/or lexis; for example, read a text and underline connectors, read a text and complete a table with rules for comparative and superlative forms, or complete a summary with verbs in the correct tense, find mistakes or common patterns in a text given. 
On the other hand, content activities were those that, through different language and cognitive skills, aimed at engaging learners with content. Such activities included: read text and decide if sentences are true or false, watch a video and complete a mind map, label a picture, match terms and definitions, complete a flowchart and produce a summary, and listen and correct wrong information in a text on migration. Activity 1 illustrates content activities.

Activity 1. Example of a content-focused activity

\begin{tabular}{|l|l|}
\hline \multicolumn{1}{|c|}{ Places } & \multicolumn{1}{|c|}{ Human impact on them } \\
\hline & \\
\hline $\begin{array}{l}\text { The T will hand out some copies containing the following chart for ss to complete } \\
\text { it while we watch a video. She will tell them: 'As you know there are amazing } \\
\text { places in the world, nature is amazing. But, the human impact on the environment } \\
\text { is terrible. Let's watch the following video and let's complete the chart.' Video: } \\
\text { https://www.youtube.com/watch?v=0zPcR7wgh0c. After watching the video, we } \\
\text { will share our findings. }\end{array}$ \\
\hline
\end{tabular}

Quantification of activities following these two broad (and crude!) categories indicated that 37 activities $(17.29 \%)$ were language-focused while 177 activities (82.71\%) were content-focused. I should stress that around 20 lesson plans did not include any language-focused activities.

As regards language activities, the trainees tended to employ language noticing and awareness strategies. Teacher-generated questions aimed at scaffolding metalinguistic reflection by making learners perceive (ir)regularities and errors. Activities usually involved asking learners to read a text and underline adjectives, verbs, cohesive markers (see Activity 2), and then classify them between comparatives and superlatives, present and past tenses, and markers of causes and consequences, respectively. Other language-focused activities included completing tables and rules, finding examples, rearranging sentences, correcting sentences, transforming sentences, and underlining cognates. 


\section{Activity 2. Example of a language-focused activity}

The teacher will divide the class into groups and she will hand them out some worksheets. She will tell them: 'The copy contains 11 facts about pollution. Underline phrases that indicate cause and circle those which indicate effect.'

1. Pollution is one of the biggest global killers, affecting over 100 million people. That's comparable to global diseases like malaria and HIV.

2. According to a 2012 study from UNICEF, 2,200 children die every day as a result of dirty drinking water.

3. 14 billion pounds of garbage are dumped into the ocean every year. Most of it is plastic.

4. Over 1 million seabirds and 100,000 sea mammals are killed by pollution every year.

5. People who live in places with high levels of air pollutants have a $20 \%$ higher risk of death from lung cancer than people who live in less-polluted areas.

6. The Mississippi River carries an estimated 1.5 million metric tons of nitrogen pollution into the Gulf of Mexico each year, creating a 'dead zone' in the Gulf each summer about the size of New Jersey.

7. Approximately $40 \%$ of the lakes in America are too polluted for fishing, aquatic life, or swimming.

8. Americans make up an estimated $5 \%$ of the world's population. However, the U.S. produces an estimated 30\% of the world's waste and uses $25 \%$ of the world's resources.

9. Each year 1.2 trillion gallons of untreated sewage, storm water, and industrial waste are dumped into U.S. water.

10. While children make up $10 \%$ of the world's population, over $40 \%$ of the global burden of disease falls on them. More than 3 million children under age five die annually from environmental factors.

11. Recycling and composting prevented 85 million tons of material away from being disposed of in 2010, up from 18 million tons in 1980.

Content-focused activities offered a wider spectrum. They were generally contained in worksheets and supported by different media, visuals, and graphic organisers (see Activity 3 ).

Learners were usually expected to work in pairs or small groups. These activities were linked to more than 1 language skill and some of them had a dual focus on language and content (for example, read a text and underline key content words and circle connectors), even when the stress was still on content/meaning over form.

In relation to the presence of language skills and vocabulary in content-focused activities $(n=177)$, results showed that there was an even distribution of oral and written skills, and lexis development (see Table 4). 


\section{Activity 3. Content-focused activity}

Before the actual search, students will be asked to think and organise their web search. I will ask them to use a mind map to organise the information they will need for their brochure. I will suggest students to use the online map mind creator bubbl.us (if students have access to computers and internet connection, otherwise they can do it in the old traditional way: paper and pencil!) The mind map should include the topics of their brochure. We can brainstorm ideas on the board. However each pair should design their own mind map. It is also important to clarify that the mind map can be enlarged or changed during the actual research according to the things students find.

E.g.

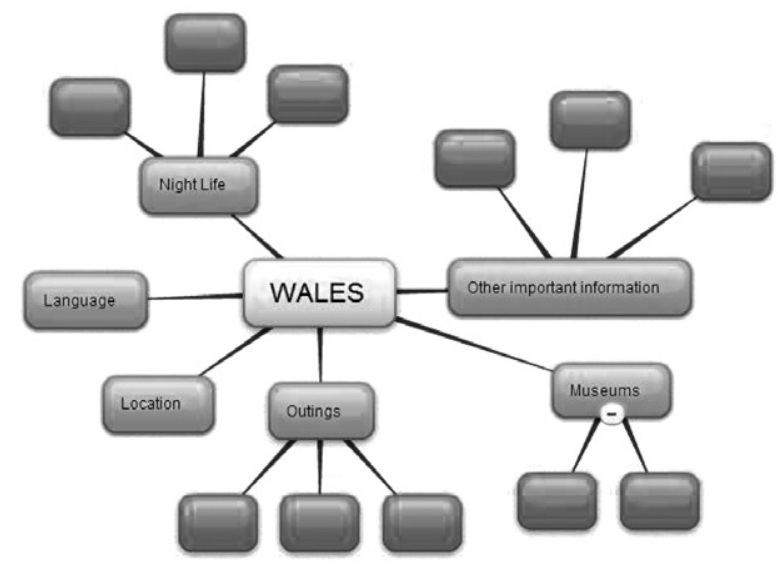

I will provide students with the following links to start looking for information to complete their mind maps:

http://www.visitwales.com/

http://www.walescoastpath.gov.uk/default.aspx

http://www.wales.com/

Students can do extra research and find their own links.

Table 4. Language skills in content-focused activities

\begin{tabular}{|l|c|}
\hline Language skills/Vocab & Percentage \\
\hline Listening & 20.34 \\
\hline Reading & 22.03 \\
\hline Speaking & 20.34 \\
\hline Writing & 18.07 \\
\hline Vocabulary & 19.21 \\
\hline
\end{tabular}


As regards cognitive skills, lessons plans offered different paths. A few plans included trainee's indications of which cognitive skills were in use with each activity. Most lesson plans consisted of activities sequenced from less to more complex activities in terms of cognitive demands. However, activities tended to remain at the level of remembering, understanding, and applying. Fewer activities encouraged analysing, evaluating, and creating (see Table 5).

\section{Table 5. Activities and cognitive processes}

\begin{tabular}{|c|l|}
\hline $\begin{array}{c}\text { Cognitive } \\
\text { process }\end{array}$ & \multicolumn{1}{c|}{ Examples of what learners needed to do } \\
\hline Remembering & $\begin{array}{l}\text { - Watch a video on rivers in America and decide if sentences are } \\
\text { true or false. The sentences contain inaccurate information. } \\
\text { summarising the text. } \\
\text { susten to their teacher talking about tourism in Argentina } \\
\text { and answer a set of questions that aim to encourage } \\
\text { memorisation of facts. }\end{array}$ \\
\hline Understanding & $\begin{array}{l}\text { - Read a text and classify adjectives between comparative and } \\
\text { superlatives. } \\
\text { - Match specific terms with their definitions. } \\
\text { - Make a mind map out of a reading passage. }\end{array}$ \\
\hline Applying & $\begin{array}{l}\text { - Carry out simple experiments. } \\
\text { - Use time connectors to explain how the respiratory system } \\
\text { works. }\end{array}$ \\
\hline Analysing & $\begin{array}{l}\text { Use specific terminology to explain how the circulatory } \\
\text { system works. }\end{array}$ \\
\hline Evaluating & $\begin{array}{l}\text { - Watch a video and take notes of main ideas only. } \\
\text { - With a partner complete reasoning gap activities around } \\
\text { population growth. }\end{array}$ \\
\hline Creating & - Produce a brochure about a city. \\
\hline
\end{tabular}

In the warm-up stage, all lessons plans promoted engagement by activating prior knowledge. Activities usually included teacher's questions, describing pictures, brainstorming ideas, or completing a short quiz. In addition, all lessons plans contained at least 1 vocabularyrelated activity, either placed in the warm-up stage or at the beginning of the development stage. Learners were usually asked to label a diagram or picture or match definitions and terms (see Activity 4). 


\section{Activity 4. Vocabulary-related activity}

The $T$ will tell ss that we are going to work in pairs to match the vocabulary with their definitions. They will be written on the board.

\section{Air pollution - Habitat - destruction - Water pollution - Poaching - Burning} is the introduction of harmful materials into the Earth's atmosphere, possibly causing disease, death to humans and damage to other living organisms.

- has traditionally been defined as the illegal hunting, killing or capturing of wild animals,

- can alter the environment much faster and causes extinctions of many species.

- the contamination of water bodies

- marked by flames or intense heat

The development stage generally consisted of activities aimed at remembering, understanding, and applying (see Table 5). However, the lesson closure did not frequently move to higher-order thinking skills. While some lesson plans included learners making a presentation supported by PowerPoint or Prezi, most lesson plans expected learners to produce a summary of the lesson's contents either through a collaboratively written text or a mind-map that reflected the process from prior knowledge to new content.

The activities collated above were linked to different materials and tools as sources of input and scaffolds for learning. Table 6 condenses trainees' preferences.

In the lesson plans, trainees who included audio-visual and Internet materials clarified that they would use interactive whiteboards, school Wi-Fi, and learners' laptops or netbooks (in Argentina there is a national programme called Conectar Igualdad through which secondary state-school learners receive a free netbook). It is worth noting that audio-visual materials represented around $70 \%$ of total material used. This percentage does not include those visual materials included in worksheets. As a personal fan of teacher-developed materials, I was glad to notice that only 3 trainees included materials taken without modification from general English course books. Trainees developed worksheets with activities from scratch or adapted activities from CLIL 
Table 6. Most used materials and tools

\begin{tabular}{|l|c|}
\hline \multicolumn{1}{|c|}{ Materials and tools } & $\begin{array}{c}\text { Number of } \\
\text { times used }\end{array}$ \\
\hline $\begin{array}{l}\text { Worksheets (including reading texts, graphic organisers, } \\
\text { pictures, and activities) }\end{array}$ & 22 \\
\hline Pictures/flashcards & 21 \\
\hline Videos & 15 \\
\hline Websites/apps & 7 \\
\hline Maps & 5 \\
\hline Realia & 5 \\
\hline Material from general English course books & 3 \\
\hline Audio files & 2 \\
\hline Graphic organisers & 2 \\
\hline PowerPoint & 1 \\
\hline Song & 1 \\
\hline
\end{tabular}

publications to exploit the potential of their selected sources of input, which are usually authentic, and the learners' level.

With this analysis in mind, in terms of lesson organisation, focus, activities, and materials, in the Discussion section I discuss links between my theoretical framework and what the trainees did.

\section{DISCUSSION}

\section{Comparing data}

This paper discusses how language-driven CLIL was envisaged by a group of 47 trainees enrolled in a teacher education course in southern Argentina. Data emerged from a survey $(n=47)$ and lesson plans $(n=39)$ aimed at secondary-school learners for whom English was usually taught two hours a week.

When survey results and content analysis of the lessons plans are compared, there are a number of issues that I would like to address before I discuss the overall results in the light of my literature review and theoretical framework. 
There are similarities in a number of aspects. In the survey (Table 1), items 1 and 2 show that the trainees usually find out what learners know about content and language at the beginning of the lesson. This is confirmed by the lesson plans, which often start with questions that trigger prior knowledge or which ask learners to brainstorm words or contents they remember. Based on this activated prior knowledge, the lesson plans also confirm item 3 (Table 1); that is, trainees' use of visuals to introduce a topic. Generally speaking, the plans show the use of pictures, diagrams, visual organisers, videos, and maps to introduce content or new subject-specific vocabulary.

Other similarities are connected to visual organisers and collaborative work as scaffolds for learning. In relation to visual organisers, items 5 and 10 (Table 1) indicate that they are usually used to scaffold learning. Lesson plans not only confirm these results but also show that all the trainees used them at least once in their plans either to activate prior knowledge, to organise new content derived from a text, or to summarise the lesson's contents. Interaction and collaboration through pair and group work (Table 1, items 6 and 9) is realised in the lesson plans. Every single plan contains at least 1 activity that involves co-constructing knowledge with peers.

One major difference between the survey and the lesson plans appears with reference to language noticing. Items 14 and 16 (Table 1) signal that the trainees have a tendency to promote language awareness. However, the lessons plans revealed that only around $20 \%$ of the total activities were language-driven, and some of them were not directed towards language noticing (for example, complete a text with the verbs in the correct tense). Nevertheless, we should remember that these are lesson plans only. My study did not include records from lesson observation.

In a similar vein, items such as 13,17 , and 18 (Table 1 ) may encourage the assumption that trainees include more activities oriented vocabulary. Although vocabulary represents 20\% (Table 4) of the total number of activities, these usually appear in the warm- 
up stage or the beginning of the development stage. They are aimed at introducing subject-specific terminology through brainstorming, labelling, or matching term and definition.

Another discrepancy emerges from thinking skills. According to item 12 (Table 1), the trainees believe that they work actively to promote learners' thinking skills. Yet lesson plans reveal that these efforts only remain at the level of remembering and understanding, even when there are activities which promote higher-order thinking skills.

In the How is language-driven CLIL conceptualised? section below, I discuss language-driven CLIL by building bridges between my selected literature and the trainees' views.

\section{HOW IS LANGUAGE-DRIVEN CLIL CONCEPTUALISED?}

In the first place, DT may help us understand how trainees engaged with different transforming operations to manage content and language in CLIL. These transformations involved delimitation, contextualisation, and localisation of content (for example, rivers $\rightarrow$ rivers in the Americas $\rightarrow$ rivers in Argentina). Content was transformed and recreated through the incorporation of learners' prior knowledge and the manipulation of different authentic sources of input to produce activities that were sequenced in growing order of complexity. These transformations included co-construction of knowledge and revisiting previous stages. For example, in 1 lesson plan, a mind-map produced in the warmup stage was continually modified after each activity.

In addition, such transformations led to active roles. The trainees exercised a powerful role as materials developers. They selected sources and produced activities around them. They became monitors, helpers, and organisers of learners' work. They did not have a central role as transmitters of knowledge. In turn, learners would not remain passive. Learners were expected to participate in the lesson actively, as their contributions and prior knowledge would help co-construct the lessons. Furthermore, some lesson plans asked learners to search 
for information and share with their peers through brochures or short presentations supported by visuals.

The steps through which DT for language-driven CLIL was enacted may confirm Richard's (2013) view that CLIL adopts a forward design to curriculum development. The trainees moved from content and language selection to materials to activities. In these transformations, Mehisto et al.'s (2008) suggestions of CLIL development around authenticity, active learning, scaffolding, and cooperation appear crystallised.

Through this forward design in CLIL, non-language/subjectmatter and language contents precede aims, materials, and activities. However, this cannot be confirmed, as my study did not include interviews with the trainees. In relation to subject-matter content, readers may have noticed that trainees exercised a preference for Science topics (Table 2). As for language, lesson plans offered grammar (for example, comparatives and superlatives), discourse features (for example, cohesive markers such as connectors), and functions (for example, summarising or describing). In connection to language, activities show that only a few trainees included activities that promoted language of/for/through learning, particularly with pair or group work activities that integrated specific terminology and the inclusion of procedures associated with, for example, carrying out an experiment or making a presentation.

Based on those contents, trainees selected aims that responded to language, content, and learning skills in general. However, the percentage of activities ( $82.71 \%$ ) devoted to content development may show that the trainees, even when aware of their role as teachers of English and the weight of language in language-driven CLIL, still concentrated on content. As regards learning skills, these were realised through both language- and content-focused activities, but these were usually linked to lower-order thinking skills such as understanding. These aims and activities were framed in a lesson structure similar to that suggested in Coyle et al. (2010). Lessons plans consisted of a 
warm-up stage for activation of prior knowledge (see Bentley, 2010), development, and a closure.

All in all, we may observe that language-driven CLIL emerged as a language-learning approach with the following features:

- It is usually aimed at B1 learners. This indicates that the trainees may believe that CLIL is effective with learners who already know 'some English.'

- It is used to teach content-specific vocabulary.

- It is based on learners' prior knowledge.

- It is useful to revise some language aspects such as tenses but not to introduce them.

- The content side serves as context for meaningful language practice and development through oral and written skills.

- It is more effective when materials are authentic, multimodal, and visual.

- It is based on collaboration between learners and the teacher.

\section{CONCLUSION}

I started this contribution by situating Latin American CLIL practices in a wider context that integrates content and language in different ways. In this case, I offered a view of how a group of trainees understood CLIL through their lesson plans.

From the data gathered, I conclude that language-driven CLIL follows forward design; it focuses more on content than on explicit knowledge of the language, and it is aimed at revising language with older learners. I observe that the trainees may believe that CLIL is an approach best suited for older or more proficient learners and that it should be implemented once learners have developed their basic language skills through other (communicative) approaches. However, these could be overgeneralisations and misinterpretations of my limited data.

Based on my findings, teacher-training opportunities should start by unpacking teachers' practices and beliefs with the aim of promoting 
critical and context-responsive pedagogies for the integration of curricular content and language learning. Initial language teacher education programmes need to incorporate CLIL based on trainees' prior experiences as learners and their possible teaching practices. In addition, modules that include CLIL should attempt to make links between CLIL practices under the light of official curricula that suggest such an approach. In this regard, there should be alignment with official curricula and context-responsive documents over other types of publications (for example, European CLIL textbooks) because teachers will be expected to respond to the former and the contents of their lessons should reflect the L1 curriculum learners engage with in the rest of the school subjects.

At the level of research, future studies and explorations should incorporate trainees' interviews (so that they explain their own lesson plans), lesson observations to compare planning and implementation, and teachers' views before, while, and after delivering a CLIL lesson. In line with Coyle (2013), future research should also incorporate learners' voices not only at the level of CLIL design and implementation but also at the level of CLIL evaluation.

\section{ACKNOWLEDGEMENTS}

This paper is based on a presentation at the 5th Biennial CLIL Symposium: New trends, challenges, and opportunities in the CLIL classroom, Universidad de La Sabana, Chía, Colombia, 12 September 2014.

\section{REFERENCES}

Adamson, J. (2014). Developing autonomy through portfolios and networks in CLIL lectures. Latin American Journal of Content and Language Integrated Learning, 7(1), 21-39. http://dx.doi. org/10.5294/laclil.2014.7.1.2

Banegas, D. L. (2011). Content and Language Integrated Learning in Argentina 2008-2011. Latin American Journal of Content 
and Language Integrated Learning, 4(2), 32-48. http://dx.doi. org/10.5294/laclil.2011.4.2.4

Banegas, D. L. (2013). The integration of content and language as a driving force in the EFL lesson. In E. Ushioda (Ed.), International perspectives on motivation: Language learning and professional challenges (pp. 82 - 97). Basingstoke, UK: Palgrave Macmillan. Banegas, D.L. (2014). Initial English language teacher education: Processes and tensions towards a unifying curriculum in an Argentinian province. English Teaching: Practice and Critique, 13(1), 224-237.

Banegas, D.L., \& Manzur Busleimán, G. (2014). Motivating factors in online language teacher education in southern Argentina. Computers \& Education, 76, 131-142.

Bentley, K. (2010). The TKT course: CLIL module. Cambridge, UK: Cambridge University Press.

Bracchi, C. (2010). Diseño curricular para la educación secundaria ciclo superior ES4: Inglés. La Plata, Argentina: Dirección General de Cultura y Educación de la Provincia de Buenos Aires.

Braun, E., Cabral, V. \& Cheme Arriaga, R. (2013). Materiales curriculares. Lengua extranjera: Inglés. Ciclo orientado de la educación secundaria. Santa Rosa, Argentina: Ministerio de Cultura y Educación, Gobierno de La Pampa.

Coyle, D. (2013). Listening to learners: An investigation into 'successful learning' across CLIL contexts. International Journal of Bilingual Education and Bilingualism, 16, 244-266.

Coyle, D., Hood, P. \& Marsh, D. (2010). CLIL: Content and language integrated learning. Cambridge, UK: Cambridge University Press. Curtis, A. (2012). Colombian teachers' questions about CLIL: What can teachers' questions tell us? (Part II). Latin American Journal of Content and Language Integrated Learning, 5(2), 1-12. http:// dx.doi.org/10.5294/laclil.2012.5.2.6

Dale, L., \& Tanner, R. (2012). CLIL activities: A resource for subject and language teachers. Cambridge, UK: Cambridge University Press. 
Dalton-Puffer, C. \& Nikula, T. (2014). Content and language integrated learning. Language Learning Journal, 42(2), 117-122.

Dalton-Puffer, C., Llinares, A., Lorenzo, F. \& Nikula, T. (2014). "You can stand under my umbrella": Immersion, CLIL and bilingual education. A response to Cenoz, Genessee \& Gorter (2013). Applied Linguistics, 35, 213-218.

Doiz, A., Lasagabaster, D. \& Sierra, J.M. (2014). CLIL and motivation: The effect of individual and contextual variables. Language Learning Journal, 42, 209-224.

Gómez Mendoza, M.A. (2005). La transposición didáctica: Historia de un concepto. Revista Latinoamericana de Estudios Educativos, 1(1), 83-115.

Koopman, G.J., Skeet, J. \& de Graff, R. (2014). Exploring content teachers' knowledge of language pedagogy: A report on a small-scale research project in a Dutch CLIL context. Language Learning Journal, 42, 123-136.

Liendo, P. J. (2012). A pragmatic approach to teaching intercultural competence to trainee teachers and translators. Latin American Journal of Content and Language Integrated Learning, 5(2), 5772. http://dx.doi.org/10.5294/laclil.2012.5.2.8

Llinares, A., Morton, T. \& Whittaker, R. (2012). The roles of language in CLIL. Cambridge, UK: Cambridge University Press.

Mariño Avila, C.M. (2014). Towards implementing CLIL (Content and Language Integrated Learning) at CBS (Tunja, Colombia). Colombian Applied Linguistics Journal, 16, 151-160.

Matear, A. (2008). English language learning and education policy in Chile: Can English really open doors for all? Asia Pacific Journal of Education, 28(2), 131-147.

Mehisto, P., Marsh, D. \& Frigols, M.J. (2008). Uncovering CLIL: Content and language integrated learning in bilingual education and multilingual education. Oxford, UK: Macmillan. 
Pinner, R. (2013). Authenticity of purpose: CLIL as a way to bring meaning and motivation into EFL contexts. Asian EFL Journal, 15(4), 138-159.

Rafel, M.V. (2011). CLIL: A rewarding experience. In D. Fernández, A.M. Armendáriz, R. Lothringer, L. Pico \& L. Anglada (Eds.), Communicative language teaching and learning revisited: What more than three decades of experience have taught us (pp. 57-60). San Miguel de Tucumán, Argentina: FAAPI.

Ravelo, L. C. (2013). The use of comic strips as a means of teaching history in the EFL class: Proposal of activities based on two historical comic strips adhering to the principles of CLIL. Latin American Journal of Content and Language Integrated Learning, 6(1), 1-19. http://dx.doi.org/10.5294/laclil.2013.6.1.1

Ravelo, L. C. (2014). Demystifying some possible limitations of CLIL (content and language integrated learning) in the EFL classroom. Latin American Journal of Content and Language Integrated Learning, 7(2), 71-82. http://dx.doi.org/10.5294/ laclil.2014.7.2.4

Richards, J.C. (2013). Curriculum approaches in language teaching: Forward, central, and backward design. RELC Journal, 44(1), 5-33.

Ruiz de Zarobe, Y. (2013). CLIL implementation: From policymakers to individual initiatives. International Journal of Bilingual Education and Bilingualism, 16, 231-243.

Ruiz de Zarobe, Y. \& Cenoz, J. (2015). Way forward in the twentyfirst century in content-based instruction: Moving towards integration. Language, Culture and Curriculum, 28, 90-96. 


\section{APPENDIX: SURVEY}

\section{Topic-based lessons: What do I do?}

\section{Year I'm completing this survey: \\ Name (optional): \\ Please, rate the following statements:}

\begin{tabular}{|c|c|c|c|c|c|}
\hline & Always & Often & Sometimes & Occasionally & Never \\
\hline $\begin{array}{l}\text { 1. At the start of a lesson, I find out what } \\
\text { learners know about the topic. }\end{array}$ & & & & & \\
\hline $\begin{array}{l}\text { 2. At the start of a lesson, I find out what } \\
\text { language related to the topic learners } \\
\text { already know. }\end{array}$ & & & & & \\
\hline 3. I use visuals to introduce new topics. & & & & & \\
\hline $\begin{array}{l}\text { 4. I use hands-on activities to introduce new } \\
\text { topics. }\end{array}$ & & & & & \\
\hline $\begin{array}{l}\text { 5. I use graphic organisers to find out and } \\
\text { organise what learners know. }\end{array}$ & & & & & \\
\hline $\begin{array}{l}\text { 6. I ask learners to talk to each other when I } \\
\text { am activating prior knowledge. }\end{array}$ & & & & & \\
\hline $\begin{array}{l}\text { 7. I provide different sorts of input to help } \\
\text { understanding. }\end{array}$ & & & & & \\
\hline $\begin{array}{l}\text { 8. I formulate different questions to promote } \\
\text { lower-order and higher-order thinking } \\
\text { skills. }\end{array}$ & & & & & \\
\hline $\begin{array}{l}\text { 9. I encourage my learners to interact through } \\
\text { pair and group work. }\end{array}$ & & & & & \\
\hline $\begin{array}{l}\text { 10. I use graphic organisers to support } \\
\text { understanding of input. }\end{array}$ & & & & & \\
\hline $\begin{array}{l}\text { 11. I use a number of strategies or activities } \\
\text { to help learners improve their reading and } \\
\text { listening skills. }\end{array}$ & & & & & \\
\hline $\begin{array}{l}\text { 12. I work actively with my learners on } \\
\text { developing their thinking skills. }\end{array}$ & & & & & \\
\hline $\begin{array}{l}\text { 13. I use a variety of activities to help my } \\
\text { learners to recycle vocabulary. }\end{array}$ & & & & & \\
\hline $\begin{array}{l}\text { 14. I help learners notice how language is used } \\
\text { in the topic of the lesson. }\end{array}$ & & & & & \\
\hline $\begin{array}{l}\text { 15. I help learners notice the similarities and } \\
\text { differences between English and their first } \\
\text { language. }\end{array}$ & & & & & \\
\hline $\begin{array}{l}\text { 16. In my classes, learners use a personal } \\
\text { vocabulary file actively. }\end{array}$ & & & & & \\
\hline $\begin{array}{l}\text { 17. I help my learners learn and use subject- } \\
\text { specific terminology. }\end{array}$ & & & & & \\
\hline $\begin{array}{l}\text { 18. I discuss ways of learning words with my } \\
\text { classes. }\end{array}$ & & & & & \\
\hline
\end{tabular}

